\title{
ЗАСТОСУВАННЯ РОЗСУДУ ПРОКУРОРОМ У ПРОЦЕСІ САНКЦІОНУВАННЯ ТА ПРОВЕДЕННЯ СЛІДЧИХ (РОЗШУКОВИХ) ДІЙ
}

Topбac 0. 0 .

у науковій статmі досліджено особливості застосування розсуду прокурором у процесі санкціонування та проведення слідчих (розшукових) дій та негласних слідчих (розшукових) дій. Автор зазначає, що під час санкціонування таких дій прокурор має керуватись нормативними вимогами та вимогами конкретного кримінального провадження. Також у статmі наголошується, що самостійне проведення прокурором гласних та негласних слідчих (розшукових) дій відбувається в разі їх особливої складності або значимості для відповідного кримінального провадження.

Ключові слова: розсуд прокурора, слідчі (розшукові) діі.

В научной статье исследовано особенности применения усмотрения прокуроров у процессе санкционирования и проведения следственных (розыскных) и негласных следственных (розыскных) действий. Автор указывает, что при санкционировании таких действий прокурор должен руководствоваться нормативными требованиями и тре бованиями конкретного уголовного производства. Также в статье указывается, что самостоятельное проведение прокурором гласных и негласных следственных (розыскных) действий происходит в случаях их особенной сложности или значимости для соответствующего уголовного производства.

Ключевые слова: усмотрение прокурора, следственные (розыскные) действия.

Torbas 0. 0. Application of prosecutor's discretion in the process of authorization and conducting of investigative (search) actions

This article is devoted to the analysis of the peculiarities of prosecutor's use of discretion in the process of authorizing and conducting investigative (search) actions and covert investigative (search) actions. In the article author notes that prosecutor in authorizing such actions must be guided by regulatory requirements and the requirements of criminal proceedings. With regard to regulatory requirements, author notes that legislator in some cases establishes conditions under which appropriate procedural actions can be carried out. Requirements of a particular criminal proceeding are much more difficult to assess. It was proposed to establish the possibility of obtaining information relevant to criminal proceedings.

In examining of prosecutor's participation in investigative (search) actions, author notes that prosecutor has the right to provide advice and recommendations to the investigator, but in no way interfere in the course of such actions.

Article also states that prosecutor conducts investigative (search) actions only in cases of extreme necessity if circumstances of the criminal proceedings require so. Legislator does not specify in which cases prosecutor should make such a decision, however, drawing an analogy with participation in procedural actions, it can be argued that prosecutor personally conducts investigative (search) actions only in case of their special

(c) Торбас О. О., 2020 complexity or significance for the relevant criminal proceedings. Prosecutor may also conduct relevant procedural actions on his own when investigator does not have enough time to carry them out. For example, circumstances of a criminal offense force several searches to be conducted simultaneously. In this case, investigator and prosecutor may share such powers and conduct several actions at the same time. Obviously, in this case, it would be more appropriate to create a group of investigators to ensure an effective pre-trial investigation. At the same time, a group of investigators can be created only by the decision of the head of pre-trial investigation agency, and prosecutor is authorized only to initiate the removal of the investigator from pre-trial investigation and only in case of ineffectiveness of such pre-trial investigation.

Key words: prosecutor's discretion, investigative (search) actions.

Постановка проблеми та їі актуальність. Кримінальне процесуальне законодавство надало досить широкі повноваження прокурору як процесуальному керівнику за діяльністю слідчого під час досудового розслідування. Це стосується також й участі прокурора у слідчих (розшукових) та негласних слідчих (розшукових) діях. Законодавець у КПК України визначає слідчого як єдиного учасника, який уповноважений проводити досудове розслідування. Однак прокурор, бувши процесуальним керівником, має право санкціонувати проведення слідчих дій, брати в них участь та навіть самостійно їх проводити. Проте, враховуючи складність кримінальних процесуальних відносин, у КПК України не встановлюється, коли саме прокурор повинен реалізовувати такі повноваження, залишаючи вирішення цих питань на його розсуд. Саме через важливість цієї проблеми у правозастосовній практиці питання реалізації розсуду прокурором у процесі санкціонування та проведення слідчих та негласних слідчих (розшукових) дій потребує наукового дослідження.

Аналіз останніх досліджень і публікацій. Проблематикою визначення ролі прокурора у процесі проведення слідчих (розшукових) та негласних слідчих (розшукових) дій переймались такі вчені, як Р.Н. Гасанов, О.Д. Гринів, В.В. Луцик, та інші. Проте цієї миті все ще відсутнє єдине комплексне дослідження розсуду прокурора під час вирішення зазначених питань.

Метою статті $\epsilon$ аналіз розсуду прокурора під час санкціонування та проведення гласних та негласних слідчих (розшукових) дій у кримінальному провадженні.

Виклад основного матеріалу. Передусім необхідно зазначити, що санкціонування проведення слідчих (розшукових) та негласних слідчих (розшукових) дій можна поділити на дві групи:

1) надання дозволу на проведення слідчих (розшукових) дій та негласних слідчих (розшукових) дій; 
2) затвердження клопотання до слідчого судді про проведення слідчих (розшукових) дій та негласних слідчих (розшукових) дій.

Прокурор надає дозвіл на проведення огляду трупа, пов'язаного з ексгумацією (ст. 239 КПК України), освідування особи (ст. 241 КПК України), контролю за вчиненням злочину (ст. 271 КПК України), виконання спеціального завдання з розкриття злочинної діяльності організованої групи чи злочинної організації (ст. 272 КПК України).

КПК України не надає чітких указівок, у яких саме випадках прокурор надає дозвіл на проведення таких дій, тому можна стверджувати, що таке рішення прокурор приймає на власний розсуд. У доктрині кримінального процесу $є$ позиція, відповідно до якої підстави проведення слідчих (розшукових) та негласних слідчих (розшукових) дій поділяються на юридичні та фактичні. У цьому разі під юридичними підставами розглядаються положення, відповідно до якого в законі міститься вказівка на те, що слідчий має право проводити певні слідчі дії за наявності відповідної постанови, а у випадках, прямо передбачених законом, - ще й за наявності санкції прокурора або дозволу суду. Відповідно, фактичні підстави являють собою дані, котрі $\epsilon$ в розпорядженні слідчого, які дозволяють зробити висновок щодо необхідності виконати в інтересах розслідування конкретну слідчу дію [1, с. 414]. Якщо взяти за основу такий загальновідомий підхід щодо класифікації підстав проведення слідчих дій, то можна зробити висновок, що прокурор під час санкціонування відповідних дій має керуватись:

1) нормативними вимогами;

2) вимогами кримінального провадження.

щодо нормативних вимог, то необхідно зазначити, що законодавець в окремих випадках установлює умови, за яких можуть бути проведені відповідні процесуальні дії. Наприклад, НСРД, котрі санкціонуються прокурором, повинні проводитись тільки у кримінальних провадженнях щодо тяжких чи особливо тяжких злочинів. Тобто такі вимоги встановити досить легко, адже вони чітко передбачені у відповідних положеннях КПК України.

Вимоги ж конкретного кримінального провадження встановити складніше. Знову-таки це пояснюється відсутністю чітких інструкції у кримінальному процесуальному законодавстві (хоча таких інструкцій i не може бути, адже законодавець не може описати всі можливі ситуації, які виникають у процесі розслідування кримінального правопорушення). КПК України містить лише базові вимоги фактичних підстав проведення відповідних процесуальних дій (ч. 2 ст. 223 КПК України - «Підставами для проведення слідчої (розшукової) дії $\epsilon$ наявність достатніх відомостей, що вказують на можливість досягнення ії мети»; ч. 2 ст. 246 КПК України - «Негласні слідчі (розшукові) дії проводяться у випадках, якщо відомості про злочин та особу, яка його вчинила, неможливо отримати в інший спосіб»). У цьому разі прокурор має ретельно дослідити наявні матеріали досудового розслідування, встановити у слідчого мету проведення відповідної дії та можливість отримання доказової інформації за результатами ії проведення. Очевидно, що на етапі санкціонування ані слідчий, ані прокурор не можуть бути певними того, що такі докази обов'язково будуть отримані, однак наявних відомо- стей у матеріалах кримінального провадження має бути достатньо для того, щоб припущення про отримання доказів було обґрунтованим.

Крім того, прокурор також обов'язково має оцінити ступінь можливого обмеження прав та законних інтересів учасників кримінального провадження у процесі проведення такої дії та співрозмірність такого обмеження із прогнозованими результатами відповідної процесуальної дії. Якщо прокурор дійде висновку, що будуть суттєво обмежені основні права та свободи особи, а докази, які планується отримати, будуть, наприклад, лише додатково підтверджувати вже встановлені факти, то більш доцільною вбачається відмова у проведенні таких дій. Крім того, має бути врахований вплив процесуальних дій на подальший перебіг досудового розслідування. Якщо, наприклад, проведення однієї слідчої (розшукової) дії унеможливить або зробить марними інші процесуальні дії через ті чи інші тактичні особливості, прокурор обов'язково має врахувати значення доказів, які можуть бути отримані, та, за необхідності, відмовити у проведенні відповідної дії чи відкласти її проведення на більш пізній етап досудового розслідування.

Саме під час вирішення таких питань найбільш яскраво проявляється прокурорський розсуд, адже прокурор повинен урахувати велику кількість обставин (як законодавчих, так і фактичних), і лише після їх зіставлення та прогнозування результативності проведення відповідних слідчих (розшукових) або негласних слідчих (розшукових) дій прокурор може прийняти рішення про надання дозволу на проведення відповідної процесуальної дії.

Схожі етапи також має пройти прокурор у процесі задоволення клопотання слідчого до слідчого судді про проведення слідчих (розшукових) або негласних слідчих (розшукових) дій. Єдиною особливістю в цьому разі буде ретельне вивчення прокурором змісту самого клопотання слідчого та перевірка його на відповідність вимогам КПК України.

Також кримінальне процесуальне законодавство дозволяє прокурору брати участь у слідчих (розшукових), негласних слідчих (розшукових) та інших процесуальних діях, котрі проводяться слідчим. Законодавець не конкретизує, в яких саме процесуальних діях прокурор може взяти участь, та в яких випадках. Однак у цьому разі необхідно звернути увагу на формулювання, яке використовується в п. 4 ч. 2 ст. 36 КПК України. Так, прокурор може «брати участь у них». Відповідно, до «них» відносяться всі процесуальні дії, які були перераховані. Тобто прокурор може брати участь і у слідчих (розшукових), і в негласних слідчих (розшукових), і в інших процесуальних діях. Р.Н. Гасанов, провівши власне дослідження, встановив, що прокурори майже не беруть участі в таких процесуальних діях (було встановлено, що частка кримінальних проваджень (від загальної кількості), в яких прокурор бере участь у проведенні слідчих (розшукових) дій, становить менше 10\%). Якщо ж прокурори беруть участь у слідчих (розшукових) діях, то такими діями найчастіше бувають обшуки та допити [2, с. 80]. Такі дані дозволяють зробити одразу декілька висновків. Так, прокурори беруть участь у слідчих (розшукових) діях лише тоді, коли для цього виникне конечна потреба. До такої крайньої необхідності можна віднести складність самої 
процесуальної дії (в такому разі прокурор може допомагати слідчому в її проведенні) або їі надзвичайну значимість для цього кримінального провадження. Із проведеного Р.Н. Гасановим дослідження можна встановити, що прокурори беруть участь у тих діях, повторне проведення яких $\epsilon$ неможливим, складним або нерезультативним. Очевидно, що якщо первинний обшук було проведено з порушеннями або не в повному обсязі, то результативність повторного обшуку буде сумнівною. Деякою мірою це стосується й допитів, адже перший допит $\epsilon$, як правило, найбільш результативним.

Досліджуючи участь прокурора в таких процесуальних діях, окремо необхідно проаналізувати, власне, обсяг повноважень, якими прокурор наділений у таких ситуаціях. Очевидно, що в разі участі прокурора слідча (розшукова) дія все одно проводиться слідчим, відповідно, саме слідчий наділений повноваженнями проводити відповідні дії та фіксувати їх результати. Прокурор не має права сам здійснювати будь-які дії, адже участь у слідчій дій не передбачає активну поведінку відповідних суб'єктів. Очевидно, що прокурор має право надавати поради та рекомендації слідчому, проте він жодним чином не повинен утручатись у перебіг іï проведення. Наприклад, якщо прокурор бере участь у проведенні допиту, то він не має права ставити питання особі, яка допитується, або складати протокол. Саме така консультативна роль прокурора у відповідних процесуальних діях і пояснює незначний обсяг слідчих дій, що проводяться за участю прокурора.

Ще однією формою участі прокурора у процесі проведення слідчих (розшукових) дій $є$ можливість прокурора самостійно такі дії проводити. Найперше необхідно зазначити, що, відповідно до ч. 6 ст. 246 КПК України, прокурор не має права проводити негласні слідчі (розшукові) дії, а тому його повноваження в частині самостійного проведення обмежені лише гласними слідчими діями.

Окрім того, прокурор може також самостійно провести відповідні процесуальні дії й тоді, якщо їх не встигатиме провести слідчий. Наприклад, обставини кримінального правопорушення змушують одночасно провести декілька обшуків. У такому разі слідчий та прокурор можуть поділити між собою такі повноваження та одночасно провести декілька процесуальних дій. Очевидно, що за таких умов більш доцільним буде створення групи слідчих у кількості, достатній для забезпечення ефективного досудового розслідування. Водночас група слідчих створюється рішенням керівника органу досудового розслідування, а прокурор, відповідно до кримінального процесуального законодавства, вповноважений лише ініціювати відсторонення слідчого від здійснення досудового розслідування, й тільки в разі неефективності досудового розслідування. Також відповідно до ч. 5 ст. 36 КПК України прокурор має право доручити здійснення досудового розслідування будь-якого кримінального правопорушення іншому органу досудового розслідування, зокрема слідчому підрозділу вищого рівня в межах одного органу, в разі неефективного досудового розслідування. Проте навіть тоді прокурор не може ініціювати створення слідчої групи чи впливати на її структуру та чисельність.

Висновки. У зв'язку із цим пропонується внести зміни до КПК України та передбачити право прокурора ініціювати перед керівником органу досудового розслідування створення слідчої групи в разі складності відповідного кримінального провадження. Для цього пропонується ч. 2 ст. 36 КПК України розширити таким пунктом: «П. $3^{1}$ ) ініціювати перед керівником органу досудового розслідування створення слідчої групи у випадках особливої складності кримінального провадження». Така зміна дозволить прокурору забезпечувати ефективність досудового розслідування в тих провадженнях, де він здійснює повноваження процесуального керівника. Крім того, така зміна не суперечить положенням КПК України в частині визначення повноважень керівника органу досудового розслідування, адже саме за ним залишається право приймати рішення про створення слідчої або слідчо-оперативної групи.

\section{Література}

1. Кримінально-процесуальне право України: підручник / за ред. Ю.П. Аленіна Харків : ТОВ «Одіссей», 2009. $816 \mathrm{c}$.

2. Гасанов Р.Н. Здійснення повноважень прокурором в частині проведення слідчих (розшукових) дій : дис. ... канд. юри. наук : 12.00.09. Одеса, 2017. 251 с.

Topбac 0. O., кандидат юридичних наук, доцент кафедри кримінального процесу Національного університету «Одеська юридична академія» 